\title{
Molecular and biological characterization of some circulating strains of Newcastle disease virus in broiler chickens from Eastern Saudi Arabia in 2012-2014
}

\author{
Abdullah I. A. Almubarak \\ Department of Microbiology, College of Veterinary Medicine, King Faisal University, Saudi Arabia. \\ Corresponding author: Abdullah I. A. Almubarak, e-mail: aialmubark@kfu.edu.sa \\ Received: 01-05-2019, Accepted: 12-09-2019, Published online: 30-10-2019
}

doi: www.doi.org/10.14202/vetworld.2019.1668-1676 How to cite this article: Almubarak AIA (2019) Molecular and biological characterization of some circulating strains of Newcastle disease virus in broiler chickens from Eastern Saudi Arabia in 2012-2014, Veterinary World, 12(10): 1668-1676.

\begin{abstract}
Background and Aim: Newcastle disease (ND) is a worldwide poultry disease that is historically known to cause severe losses in the poultry industry. In the present study, attempts were made to characterize ND virus (NDV) recovered from broiler chickens in the Eastern Region of Saudi Arabia from January 2012 to March 2014.

Materials and Methods: Reverse transcription-polymerase chain reaction was used for the detection of NDV followed by partial sequencing of the fusion (F) gene. The intracerebral pathogenicity index (ICPI), mean death time (MDT), and complete sequencing of the hemagglutinin-neuraminidase (HN) gene were also used for further biological and molecular characterization.

Results: NDV was detected at a rate of 9.6\% (11/115) of the tested flocks, most of which were vaccinated against ND. F gene-based phylogeny and motifs of the fusion protein cleavage site (FPCS) showed segregation of Saudi isolates into two groups. The first group contained 10 isolates and was located in genotype II with the lentogenic motif ${ }^{112}$ GRQGRL ${ }^{117}$ at the FPCS. The second group contained one isolate and was located in genotype VII with velogenic motif ${ }^{112} \mathrm{RRQKRF}{ }^{117}$. Further characterization using the ICPI and MDT of two representative isolates showed virulence of both tested isolates. Phylogenetic analysis of the HN gene showed close nucleotide identity between the two isolates. A BLAST search for sequences similar to HN gene sequences showed high identity with isolates from the surrounding region.
\end{abstract}

Conclusion: The present findings showed a low detection rate of NDV, possibly due to the wide application of vaccines, and the circulation of at least two NDV genotypes, II and VII, in the Eastern Region of Saudi Arabia. The present Saudi isolates may share common ancestors with isolates from the surrounding region.

Keywords: broiler chickens, Newcastle disease virus, Saudi Arabia.

\section{Introduction}

Newcastle disease (ND) is one of the most important poultry diseases in terms of the number of birds lost [1]. The causative agent, ND virus (NDV), is an avian paramyxovirus type I (APMV-1) belonging to the genus Avulavirus and family Paramyxoviridae [2]. It has the ability to infect a wide range of avian species, and 240 bird species were reported to be susceptible $[3,4]$. Wild and domesticated birds were implicated as a reservoir of NDV and a possible mode of dissemination $[5,6]$. According to the World Organization for Animal Health (OIE), the presence of multiple basic amino acids at the fusion protein cleavage site (FPCS) and/ or an intracerebral pathogenicity index (ICPI) of $\geq 0.7$ is required to designate APMV-1 as the cause of an ND outbreak [7]. The mean death time (MDT) is also

Copyright: Almubarak. Open Access. This article is distributed under the terms of the Creative Commons Attribution 4.0 International License (http://creativecommons.org/licenses/by/4.0/), which permits unrestricted use, distribution, and reproduction in any medium, provided you give appropriate credit to the original author(s) and the source, provide a link to the Creative Commons license, and indicate if changes were made. The Creative Commons Public Domain Dedication waiver (http://creativecommons.org/ publicdomain/zero/1.0/) applies to the data made available in this article, unless otherwise stated. frequently used to classify APMV-1 as velogenic (MDT $<60 \mathrm{~h}$ ), mesogenic (MDT 60-90 h), and lentogenic (MDT $>90$ h) [8]. Phylogenetically, NDV has been genotyped into two major clades: Class I and Class II. Class I is divided into nine genotypes (1-9) and is mostly composed of avirulent viruses for chickens. Class II viruses occur in at least 18 genotypes (I-XVIII) and include most virulent as well as some avirulent and vaccine strains [9-11]. Alternatively, these genotypes are rearranged in six lineages (1-6). Genotypes I, II, VI, and VII are renamed lineages 1, 2, 4, and 5, respectively. Genotypes III, IV, V, and VIII are grouped into a single lineage called lineage 3 [12]. The sixth lineage includes viruses with high antigenic and genetic divergence from APMV-1 and viruses that belong to Class I $[8,12]$. Due to the confusion ensuing from the simultaneous use of these two systems, Diel et al. proposed a unified nomenclature in which Class I is renamed genotype 1, 10 genotypes of Class II retain their names (genotypes I-IX and XI), and five new genotypes are added, genotypes X, XII, XIII, XIV, and XV [13].

In the Middle East, ND outbreaks have occurred since the late 1960s [14]. ND records in Saudi Arabia go back to the 1980 s when velogenic NDV 
strains were reported by El-Zein [15]. Isolates from Saudi Arabia were typed as lineages $4 b, 4 c$, and $5 d$ (genotypes VI and VII) based on the fusion (F) gene phylogeny [12]. Isolates belonging to genotype VIId were also recently reported [16]. Poultry in Saudi Arabia has experienced high mortality rates in recent years [17]. Among the affected regions is the Eastern Region of Saudi Arabia, which was estimated to produce 37,598,000 broiler chickens and 1,197,306,000 eggs in 2017 [18].

To elucidate the role played by NDV in these mortalities, a survey targeting this virus was launched in the Eastern Region of Saudi Arabia. Herein, we report the characterization of circulating NDV in this region from 2012 to 2014.

\section{Materials and Methods}

\section{Ethical approval}

All experimental procedures and management conditions used in this study were approved by the Ethics Committee at King Faisal University, Saudi Arabia.

\section{Study design}

Tissue samples were collected from broiler chickens in the Eastern Region of Saudi Arabia. Nucleic acid was extracted and NDV was detected using reverse transcription-polymerase chain reaction (RT-PCR). Part of the F gene, including the region encoding FPCS, was sequenced to genotype the detected virus. NDV was isolated in embryonated specific-pathogen-free (SPF) eggs to perform in vivo biotyping. Two representative isolates were selected to carry out the more aggressive procedure, ICPI analysis. In addition, MDT analysis and sequencing of the complete hemagglutinin-neuraminidase $(\mathrm{HN})$ gene were also performed for the two representative isolates.

\section{Sample collection and processing}

Tissue samples, including those from the trachea and lung, were collected from broiler chickens in the Eastern Region (Al-Hasa and Dammam) of Saudi Arabia from January 2012 to March 2014. Purposive sampling was used to collect samples from broilers with signs of respiratory illness such as nasal discharge, rales, and gasping. Samples were collected from commercial poultry farms, poultry slaughterhouses, and poultry clinic at the Veterinary Teaching Hospital of King Faisal University. Attempts were made to collect complete history for sampled flocks. All samples were collected from commercial farms with several sheds on each farm. The number of chicks per shed varied from 10,000 to 15,000 chicks. Biosecurity measures were applied at the majority of the farms and included minimizing the entrance of visitors and vehicles and, when visitors and vehicles were allowed to enter, disinfecting the vehicles and having visitors wear special clothes and boots. Visiting other farms and the transport of litter, equipment or birds between farms were not permitted. Dead birds and litter were disposed of as directed by veterinarians. Measures were also taken to avoid the entrance of wild animals and the transmission of infection from hatcheries. The farms were separated by approximately $10 \mathrm{~km}$ or more. For each flock, tissue samples from each organ from all sampled birds were pooled together and treated as a single sample. Samples were collected in 10 volumes of phosphate-buffered saline (PBS) containing gentamicin and nystatin, both at a concentration of $50 \mu \mathrm{g} / \mathrm{ml}$ and stored at $-80^{\circ} \mathrm{C}$ until homogenization. Homogenization was performed with the Biospec Mini-Beadbeater and the Omni International Ceramic Beads kit. An IQeasy Plus Viral DNA/RNA Extraction kit (Cat \# 17153, iNtRON Biotechnology, South Korea) was used according to the manufacturer's instructions to extract viral RNA from homogenized tissues. Extracted RNA was stored at $-80^{\circ} \mathrm{C}$ until use to produce cDNA by the Reverse Transcription System (Cat \# A3500, Promega, USA) according to the manufacturer's instructions.

\section{Detection and genotyping of NDV}

Detection and genotyping of NDV were performed using nested PCR as previously described by Nanthakumar et al. [19]. Primers were obtained from Integrated DNA Technologies (IDT, Coralville, IA). For detection, GoTaq ${ }^{\circledR}$ Green Master Mix (Cat \# M7122, Promega) was used in a final volume of $25 \mu \mathrm{l}$ that contained primers at a final concentration of $0.8 \mu \mathrm{M}$. For genotyping, the reaction was repeated with positive samples using the i-StarMAX II Master Mix (Cat \# 25174, iNtRON Biotechnology) at a final volume of $50 \mu 1$ with a final primer concentration of $0.2 \mu \mathrm{M}$. Similarly, PCR targeting the HN gene was also used for genotyping as previously described by Tan et al. [20]. PCR products were purified using the Wizard SV Gel and PCR Clean-up System (Cat \# A1460, Promega) according to the manufacturer's instructions. Purified amplicons were sequenced by Macrogen Sequencing Service (South Korea).

\section{Sequence analysis}

Sequence analysis was performed using Molecular Evolutionary Genetics Analysis (MEGA) $\mathrm{X}$ software [21]. Sequences were aligned using ClustalW. A phylogenetic tree was constructed using the maximum likelihood method with a bootstrap value of 1000 replicates. A BLAST search was performed to determine the most related sequences in GenBank. F gene-based phylogenic classification of Diel et al. [13] was followed to prepare the phylogenetic tree. Reference sequences representing the genotypes and subgenotypes in the Diel classification were used. Genotype XV, which was previously reported to harbor recombinant strains, was not included [22-24]. For the HN gene-based phylogeny, reference sequences from a similar study of the region [20] were used, as were the most similar sequences found in BLAST analysis. Sequence identity is the number 
of identical nucleotides between pairs of sequences divided by the total length of aligned sequences.

\section{GenBank accession number}

Sequences obtained from the present 11 isolates of NDV were deposited in GenBank with the following accession numbers: MK608020-MK608024 and MK660772-MK660777 for F gene sequences and MK660778 and MK660779 for HN gene sequences, as shown in Table-1.

\section{Isolation}

Isolation was carried out in SPF embryonated eggs (Nile SPF, Egypt) according to Alexander [25]. Before inoculation, homogenized tissue samples were centrifuged at $1000 \times \mathrm{g}$ for $10 \mathrm{~min}$. The centrifugation-derived supernatant was passed through a $0.2 \mu \mathrm{m}$ sterile nylon syringe filter (Thermo Scientific, Nalgene ${ }^{\circledR}$, Cat \#195-2520, USA). A $200 \mu 1$ volume of filtrated liquid was inoculated into the allantoic cavity in 10-day-old embryonated eggs. Embryonic death during the first $24 \mathrm{~h}$ was considered non-specific. Thereafter, embryonic deaths were considered as indicators of the presence of NDV, and allantoic fluids (AFs) were harvested.

MDT

MDT was measured following the method described by Grimes [26]. Ten-fold serial dilutions $\left(10^{-1}-10^{-9}\right)$ of the AFs were prepared in sterile PBS. Each dilution was inoculated into five 10-day-old SPF embryonated eggs (Nile SPF). One hundred microliters were inoculated in the allantoic cavity. Eggs were then sealed with paraffin wax and incubated at $37^{\circ} \mathrm{C}$. Eggs were candled every $8 \mathrm{~h}$ for 7 days. The highest virus dilution that induced the death of all inoculated embryos was considered the minimal lethal dose, and the meantime (hours) required for this dilution to kill inoculated embryos was considered the MDT.

\section{ICPI}

ICPI analysis was carried out according to OIE [7]. SPF chicks (Nile SPF) aged 30-40 h were used for this test. Briefly, fresh AF with hemagglutination (HA) titer of $2^{5}$ was diluted in sterile normal saline (1/10), and $50 \mu 1$ was injected intracerebrally into 10 chicks for each sample. Chicks were observed daily for 8 days and scored 0 if normal, 1 if sick, and 2 if dead. The index was calculated as the mean score per bird per observation over the 8 days.

\section{Results and Discussion}

\section{NDV detection}

During the study period, a total of 115 flocks were sampled. Samples were tested for the presence of NDV using RT-PCR. The results showed that $11(9.6 \%)$ samples were positive for NDV. Table-1 presents the data on the NDV-positive samples. This value is comparable to the previously reported $10 \%$ NDV prevalence in Bangladesh [27]. Higher prevalence of $41.6 \%$ in Jordan [28], $60 \%$ in Ghana [29], and $62 \%$ in Egypt [30] were reported. In all of these cases, diseased flocks were targeted; however, a much lower prevalence is expected when samples are collected regardless of disease status, as in Brazil, where $0.7 \%$ was reported [31].

Table-1: Data on the NDV-positive samples.

\begin{tabular}{|c|c|c|c|c|c|c|c|}
\hline Sample ID & $\begin{array}{l}\text { Date of } \\
\text { collection }\end{array}$ & $\begin{array}{c}\text { Age } \\
\text { (days) }\end{array}$ & $\begin{array}{c}\text { Number of } \\
\text { sampled birds }\end{array}$ & Governorate & $\begin{array}{l}\text { NDV vaccine-age } \\
\text { of vaccination }\end{array}$ & $\begin{array}{l}\text { Detected NDV } \\
\text { genotype }\end{array}$ & $\begin{array}{l}\text { GB \# of F } \\
\text { gene }\end{array}$ \\
\hline $\begin{array}{l}\text { NDV-SA/ } \\
\text { Chicken/NH3 }\end{array}$ & $\begin{array}{l}\text { April 23, } \\
2012\end{array}$ & 30 & 20 & Dammam & $\begin{array}{l}\text { B1-1 day; } \\
\text { LaSota-18 days }\end{array}$ & $\begin{array}{l}\text { Avirulent } \\
\text { genotype II }\end{array}$ & MK660776 \\
\hline $\begin{array}{l}\text { NDV-SA/ } \\
\text { Chicken/NH10 }\end{array}$ & $\begin{array}{l}\text { March 5, } \\
2013\end{array}$ & 14 & 5 & Hasa & B1-1 day & $\begin{array}{l}\text { Virulent } \\
\text { genotype II }\end{array}$ & MK660772 \\
\hline $\begin{array}{l}\text { NDV-SA/ } \\
\text { Chicken/NH12 }\end{array}$ & $\begin{array}{l}\text { March 12, } \\
2013\end{array}$ & 21 & 8 & Hasa & $\begin{array}{l}\text { Clone } 30-1 \text { day; } \\
\text { Clone } 30-14 \text { days }\end{array}$ & $\begin{array}{l}\text { Virulent } \\
\text { genotype II }\end{array}$ & MK660773 \\
\hline $\begin{array}{l}\text { NDV-SA/ } \\
\text { Chicken/NH17 }\end{array}$ & $\begin{array}{l}\text { November } \\
27,2013\end{array}$ & 46 & $>20$ & Hasa & $\begin{array}{l}\text { B1-1 day; Clone } \\
\text { 30-20 days }\end{array}$ & $\begin{array}{l}\text { Virulent } \\
\text { genotype VII }\end{array}$ & MK608022* \\
\hline $\begin{array}{l}\text { NDV-SA/ } \\
\text { Chicken/NH22 }\end{array}$ & $\begin{array}{l}\text { December } \\
15,2013\end{array}$ & 31 & $>20$ & Hasa & $\begin{array}{l}\text { Clone- } 1 \text { day; } \\
\text { Clone } 30-20 \text { days }\end{array}$ & $\begin{array}{l}\text { Virulent } \\
\text { genotype II }\end{array}$ & MK660774 \\
\hline $\begin{array}{l}\text { NDV-SA/ } \\
\text { Chicken/NH24 }\end{array}$ & $\begin{array}{l}\text { December } \\
17,2013\end{array}$ & 11 & $>20$ & Hasa & B1-1 day & $\begin{array}{l}\text { Virulent } \\
\text { genotype II }\end{array}$ & MK608023* \\
\hline $\begin{array}{l}\text { NDV-SA/ } \\
\text { Chicken/NH25 }\end{array}$ & $\begin{array}{l}\text { December } \\
29,2013\end{array}$ & 34 & $>20$ & Dammam & $\begin{array}{l}\text { B1-1 day; Clone } \\
30-20 \text { days }\end{array}$ & $\begin{array}{l}\text { Virulent } \\
\text { genotype II }\end{array}$ & MK608024 \\
\hline $\begin{array}{l}\text { NDV-SA/ } \\
\text { Chicken/NC3 }\end{array}$ & $\begin{array}{l}\text { February } \\
10,2013\end{array}$ & 34 & 1 & Hasa & $\begin{array}{l}\text { B1-1 day; } \\
\text { LaSota-16 days }\end{array}$ & $\begin{array}{l}\text { Avirulent } \\
\text { genotype II }\end{array}$ & MK608020 \\
\hline $\begin{array}{l}\text { NDV-SA/ } \\
\text { Chicken/NC19 }\end{array}$ & $\begin{array}{l}\text { May 27, } \\
2013\end{array}$ & 37 & 1 & Hasa & $\begin{array}{l}\text { B1-1 day; } \\
\text { LaSota-20 days }\end{array}$ & $\begin{array}{l}\text { Avirulent } \\
\text { genotype II }\end{array}$ & MK660777 \\
\hline $\begin{array}{l}\text { NDV-SA/ } \\
\text { Chicken/NC37 }\end{array}$ & 2013 & NA & 1 & Hasa & NA & $\begin{array}{l}\text { Avirulent } \\
\text { genotype II }\end{array}$ & MK660775 \\
\hline $\begin{array}{l}\text { NDV-SA/ } \\
\text { Chicken/NC60 }\end{array}$ & 2013 & NA & 1 & Hasa & NA & $\begin{array}{l}\text { Virulent } \\
\text { genotype II }\end{array}$ & MK608021 \\
\hline
\end{tabular}

NA=Data were not available, GB\#=GenBank accession number, *MK660779 and MK660778 are the GenBank accession numbers for the HN gene of NDV-SA/Chicken/NH17 and NDV-SA/Chicken/NH24, respectively. The sample pairs NDV-SA/ Chicken/NH3 with NDV-SA/Chicken/NH25, NDV-SA/Chicken/NH12 with NDV-SA/Chicken/NC3, and NDV-SA/Chicken/ $\mathrm{NH} 17$ with NDV-SA/Chicken/NH24 were collected from the same farms but different periods, flocks, and sheds. $\mathrm{NDV}=$ Newcastle disease virus 


\section{Partial F gene-based phylogeny and FPCS}

According to the classification of Diel et al. [13], the present $11 \mathrm{NDV}$ isolates segregated into two genotypes (Figure-1). The first group was located within genotype II with $99-100 \%$ nucleotide identity to each other. The second group contained only one isolate that clustered with reference sequences from genotype VII. The deduced amino acid sequences of the FPCS showed two motif types compatible with the results of the $\mathrm{F}$ gene phylogeny. The 10 isolates in genotype II revealed the lentogenic motif ${ }^{112} \mathrm{GRQGRL}^{117}$ at the FPCS. The single isolate in genotype VII showed the velogenic motif ${ }^{112}$ RRQKRF ${ }^{117}$ at the FPCS. This is in agreement with results from the Eastern Region of Saudi Arabia recently reported by Al-Ali et al. [16], where genotype VII was detected during the years 2015/2016.

Isolates belonging to genotype II may originate from vaccine strains. The commonly used live attenuated vaccines, including LaSota, Hitchner-B1, Clone 30, and VG/GA strains, all belong to genotype II [32]. On the other hand, genotype VII has been reported in Eastern Asia since 1985 and has been divided into two subgenotypes, VIIa and VIIb. The former includes viruses that spread to Europe and Asia, while the latter includes viruses that spread to South Africa. Subsequently, additional subgenotypes were added, including VIIc, VIId, and VIIe containing isolates from China, Kazakhstan, and South Africa and VIIf, VIIg, and VIIh consisting of African isolates [9].
Collectively, genotype VII became the most prevalent NDV genotype in Asia and Europe and was incriminated in causing the fourth NDV panzootic that started in Southeast Asia in the early 1990s. Within this genotype, subtype VIId, to which the present Saudi isolate belongs, appears to be the most predominant subtype [33-37].

\section{Isolation and BLAST search}

A BLAST search for sequences similar to the partial $\mathrm{F}$ gene sequences yielded a result compatible with observations from NDV isolation. Isolation in SPF embryonated eggs revealed that seven isolates were able to induce embryonic death in inoculated eggs during the $2^{\text {nd }}$ and $3^{\text {rd }}$ days post-inoculation. The remaining four isolates of genotype II were not able to induce embryonic death in inoculated eggs. A BLAST search for the 10 isolates revealed that Chinese strain HA-3-07-Ch and LaSota vaccine (GB\#: GQ245765; AF077761) are the most similar sequences in GenBank, with 98-99\% nucleotide identity. A BLAST search for the NDV-SA/Chicken/NH17 isolate of genotype VII revealed that the strain most closely related to this isolate was the NDV/Chicken/2/SA/2016 (GB\# MG022112), with 97.6\% nucleotide identity. Based on the available overlapped sequence (167 nt), 96.4\% nucleotide identity was also found with the previously reported genotype VII Saudi isolate ISACK00184 (GB \# AY135754) that was isolated in 2000. Comparing

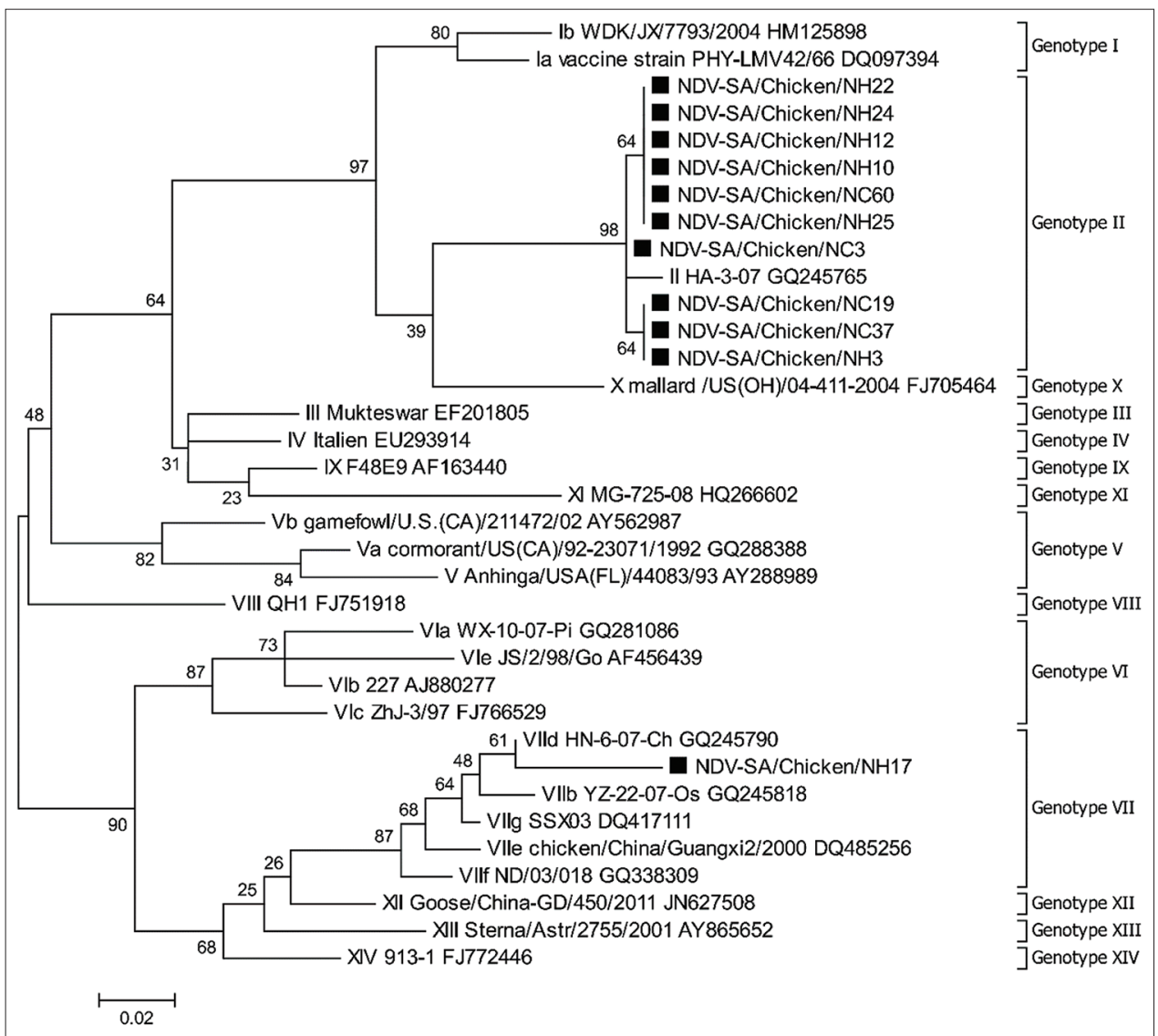

Figure-1: Partial F gene-based phylogeny showing the relationship between Saudi Newcastle disease virus isolates and reference sequences. The present Saudi isolates are marked with black squares. Reference sequences end with their GenBank accession numbers. 
the present Saudi NDV sequences with the three most similar reference sequences revealed the nucleotide substitutions presented in Table-2.

\section{In vivo biotyping by ICPI and MDT analyses}

Two Saudi isolates, NDV-SA/Chicken/NH17 and NDV-SA/Chicken/NH24, representing genotype VII and genotype II, respectively, were selected for further characterization by ICPI and MDT analyses. Both isolates showed a high ICPI: 1.54 in the case of NDV-SA/Chicken/NH17 and 1.6 in the case of NDV-SA/Chicken/NH24. Similarly, the MDT was measured for both isolates and was $52 \mathrm{~h}$ for NDV-SA/ Chicken/NH24 and $57 \mathrm{~h}$ for NDV-SA/Chicken/NH17. Tables-3 and 4 summarize the results of the molecular and biological characterizations and the clinical signs associated with the present NDV isolates.

\section{Complete HN gene-based phylogeny}

$\mathrm{HN}$ gene-based phylogenic analysis of the two representative isolates (NDV-SA/Chicken/NH17 and NDV-SA/Chicken/NH24) showed that the isolates were related to each other with $98.2 \%$ nucleotide identity (Figure-2 and Table-5). Both sequences clustered in genotype VII. A BLAST search showed that Chinese strain XJ-2/97 (GB\# JN618348) was the most closely related sequence in GenBank, with nucleotide identities of $96 \%$ and $96.4 \%$ with NDV-SA/ Chicken/NH17 and NDV-SA/Chicken/NH24, respectively. Nucleotide comparison with sequences belonging to genotype VII revealed identities ranging between $91.5 \%$ and $96.4 \%$. The nucleotide identities with sequences from the other genotypes were $\leq 88.3 \%$ (Table-5).

There was an inconsistency regarding the characteristics of the NDV-SA/Chicken/NH24 isolate. Partial F gene phylogeny and FPCS motif indicated that this isolate belongs to genotype II. In vivo biotyping showed virulence comparable to that of genotype VII. This was further supported by the complete HN gene phylogeny that showed NDV-SA/Chicken/ NH24 as a part of genotype VII. One possible explanation for this confusion is the presence of mixed infection with both virulent genotype VII and vaccine strain belonging to genotype II. In this regard, the

Table-2: Comparison of the present Saudi sequences with the three most similar sequences in BLAST over the sequenced region of the $\mathrm{F}$ gene.

\begin{tabular}{|c|c|c|c|c|c|c|c|c|c|c|c|c|c|c|c|}
\hline $\begin{array}{l}\text { Nt position in the F gene } \\
\text { according to GB\# M24693 }\end{array}$ & $\begin{array}{c}\text { GenBank } \\
\text { accession \# }\end{array}$ & 286 & 289 & 292 & 298 & 347 & 375 & 418 & 430 & 439 & 458 & 463 & 481 & 484 & 490 \\
\hline \multicolumn{16}{|l|}{ Genotype VII } \\
\hline NDV-SA/Chicken/NH17 & MK608022 & G & G & - & C & - & A & C & $\mathrm{T}$ & G & - & $A$ & $\mathrm{~T}$ & $A$ & $\mathrm{~T}$ \\
\hline NDV/Chicken/2/SA/16 & MG022112 & $A$ & A & - & $\mathrm{T}$ & - & A & C & $\mathrm{T}$ & G & - & A & C & A & C \\
\hline NDV-SA-1SACK00184/00 & AY135754 & $A$ & $A$ & - & $\mathrm{T}$ & - & G & $\mathrm{T}$ & G & G & $?$ & $?$ & $?$ & $?$ & $?$ \\
\hline NDV-China/Chicken/HN-6-07-Ch & GQ245790 & A & G & - & $\mathrm{T}$ & - & A & $\mathrm{T}$ & G & A & - & G & C & G & $\mathrm{T}$ \\
\hline \multicolumn{16}{|l|}{ Genotype II } \\
\hline NDV-SA/Chicken/NH24* & MK608023 & G & - & G & - & G & - & - & - & - & G & - & $\mathrm{T}$ & - & - \\
\hline NDV-SA/Chicken/NH3** & MK660776 & G & - & G & - & A & - & - & - & - & C & - & $\mathrm{T}$ & - & - \\
\hline NDV-SA/Chicken/NC3 & MK608020 & G & - & G & - & $A$ & - & - & - & - & G & - & $\mathrm{T}$ & - & - \\
\hline NDV-B1 & AF309418 & C & - & $\mathrm{T}$ & - & $A$ & - & - & - & - & G & - & $A$ & - & - \\
\hline NDV-LaSota & AF077761 & C & - & $\mathrm{T}$ & - & $A$ & - & - & - & - & G & - & $A$ & - & - \\
\hline NDV-HA-3-07-Ch/07 & GQ245765 & $\mathrm{C}$ & - & $\mathrm{T}$ & - & A & - & - & - & - & $\mathrm{G}$ & - & $\mathrm{T}$ & - & - \\
\hline
\end{tabular}

-=identical nucleotide; ?=sequence not available. *Sequences NDV-SA/Chicken/NH10, NDV-SA/Chicken/NH12, NDV-SA/ Chicken/NH22, NDV-SA/Chicken/NH25, and NDV-SA/Chicken/NC60 showed complete identities with the NDV-SA/ Chicken/NH24 sequence.**Sequences NDV-SA/Chicken/NC19 and NDV-SA/Chicken/NC37 showed complete identities with the NDV-SA/Chicken/NH3 sequence. NDV=Newcastle disease virus

Table-3: Summary of the molecular and biological characterization of the Saudi NDV isolates.

\begin{tabular}{|c|c|c|c|c|c|c|c|}
\hline \multirow[t]{2}{*}{ Isolate } & \multicolumn{4}{|c|}{ Molecular characterization } & \multicolumn{3}{|c|}{ Biological characterization } \\
\hline & $\begin{array}{l}\text { F gene-based } \\
\text { genotyping }\end{array}$ & $\begin{array}{c}* \text { F gene BLAST } \\
(\text { GB \#) }\end{array}$ & $\begin{array}{c}\text { FPCS } \\
(112-117)\end{array}$ & $\begin{array}{l}\text { HN gene-based } \\
\text { genotyping }\end{array}$ & $\begin{array}{l}\text { Lethality to } \\
\text { embryonated eggs }\end{array}$ & $\begin{array}{l}\text { MDT } \\
(\mathbf{h})\end{array}$ & ICPI \\
\hline NDV-SA/Chicken/NH3 & II & AF077761 & GRQGRL & -- & - & -- & -- \\
\hline NDV-SA/Chicken/NH10 & II & GQ245765 & GRQGRL & -- & + & -- & -- \\
\hline NDV-SA/Chicken/NH12 & II & GQ245765 & GRQGRL & -- & + & -- & -- \\
\hline NDV-SA/Chicken/NH17 & VII & MG022112 & RRQKRF & VII & + & 57 & 1.54 \\
\hline NDV-SA/Chicken/NH22 & II & GQ245765 & GRQGRL & -- & + & -- & -- \\
\hline NDV-SA/Chicken/NH24 & II & GQ245765 & GRQGRL & VII & + & 52 & 1.6 \\
\hline NDV-SA/Chicken/NH25 & II & GQ245765 & GRQGRL & -- & + & -- & -- \\
\hline NDV-SA/Chicken/NC3 & II & AF077761 & GRQGRL & -- & - & -- & -- \\
\hline NDV-SA/Chicken/NC19 & II & AF077761 & GRQGRL & -- & - & -- & -- \\
\hline NDV-SA/Chicken/NC37 & II & AF077761 & GRQGRL & -- & - & -- & -- \\
\hline NDV-SA/Chicken/NC60 & II & GQ245765 & GRQGRL & -- & + & -- & -- \\
\hline
\end{tabular}

-- not determined; *GenBank accession number of most similar sequence in BLAST. NDV=Newcastle disease virus, $\mathrm{HN}=$ Hemagglutinin-neuraminidase, FPCS=Fusion protein cleavage site, ICPI=Intracerebral pathogenicity index, MDT $=$ Mean death time 
Table-4: Relevant clinical data on groups of Saudi NDV isolates according to their molecular and biological characteristics.

\begin{tabular}{|c|c|c|c|c|}
\hline $\begin{array}{l}\text { Molecular/ } \\
\text { biological } \\
\text { group } \\
\end{array}$ & $\begin{array}{l}\text { Genotype II, } \\
\text { not lethal to } \\
\text { embryonated eggs }\end{array}$ & $\begin{array}{l}\text { Genotype II, lethal to } \\
\text { embryonated eggs }\end{array}$ & Genotype VII & $\begin{array}{l}\text { Ambiguous isolate } \\
\text { (genotypes II/VII) }\end{array}$ \\
\hline Isolates & $\begin{array}{l}\text { NDV-SA/Chicken/NH3, } \\
\text { NDV-SA/Chicken/NC3, } \\
\text { NDV-SA/Chicken/NC19 } \\
\text { NDV-SA/Chicken/NC37* }\end{array}$ & $\begin{array}{l}\text { NDV-SA/Chicken/NH10, } \\
\text { NDV-SA/Chicken/NH12, } \\
\text { NDV-SA/Chicken/NH22, } \\
\text { NDV-SA/Chicken/NH25, } \\
\text { NDV-SA/Chicken/NC60* }\end{array}$ & NDV-SA/Chicken/NH17 & $\begin{array}{l}\text { NDV-SA/Chicken/ } \\
\text { NH24 }\end{array}$ \\
\hline Clinical picture & $\begin{array}{l}\text { In general, there were } \\
\text { mild respiratory signs, } \\
\text { nasal discharge, and } \\
\text { rales }\end{array}$ & $\begin{array}{l}\text { Unthriftiness, depression, } \\
\text { nasal discharge, gasping, } \\
\text { and rales }\end{array}$ & $\begin{array}{l}\text { Many birds showed } \\
\text { depression, nasal } \\
\text { discharge, gasping, } \\
\text { coughing, rales, and } \\
\text { conjunctivitis }\end{array}$ & $\begin{array}{l}\text { Similar to that of } \\
\text { NDV-SA/Chicken/ } \\
\text { NH17 }\end{array}$ \\
\hline $\begin{array}{l}\text { Mortality/1000 } \\
\text { chicks in the } \\
\text { day preceding } \\
\text { sample } \\
\text { collection }\end{array}$ & $\begin{array}{l}5 \text { chicks in the source } \\
\text { of isolate NDV-SA/ } \\
\text { Chicken/NC19 }\end{array}$ & $\begin{array}{l}20 \text { chicks in the source of } \\
\text { isolate NDV-SA/Chicken/ } \\
\text { NH } 22 \text { and } 35 \text { chicks in the } \\
\text { source of isolate NDV-SA/ } \\
\text { Chicken/NH10 }\end{array}$ & 40 chicks & 21 chicks \\
\hline $\begin{array}{l}\text { Postmortem } \\
\text { examination }\end{array}$ & $\begin{array}{l}\text { Congestion and exudate } \\
\text { in trachea }\end{array}$ & $\begin{array}{l}\text { Congestion and exudate in } \\
\text { trachea and congestion of } \\
\text { intestine. In some birds, } \\
\text { congestion and enlargement } \\
\text { of kidneys were seen }\end{array}$ & $\begin{array}{l}\text { Congestion of trachea, } \\
\text { intestine, and kidney and } \\
\text { enlargement of kidney and } \\
\text { spleen. Purulent pneumonia } \\
\text { was seen in some birds }\end{array}$ & $\begin{array}{l}\text { Congestion of trachea } \\
\text { and intestine, exudate } \\
\text { in tracheas, and } \\
\text { enlargement of spleen }\end{array}$ \\
\hline
\end{tabular}

*Farms separated by approximately $10 \mathrm{~km}$ or more. NDV=Newcastle disease virus

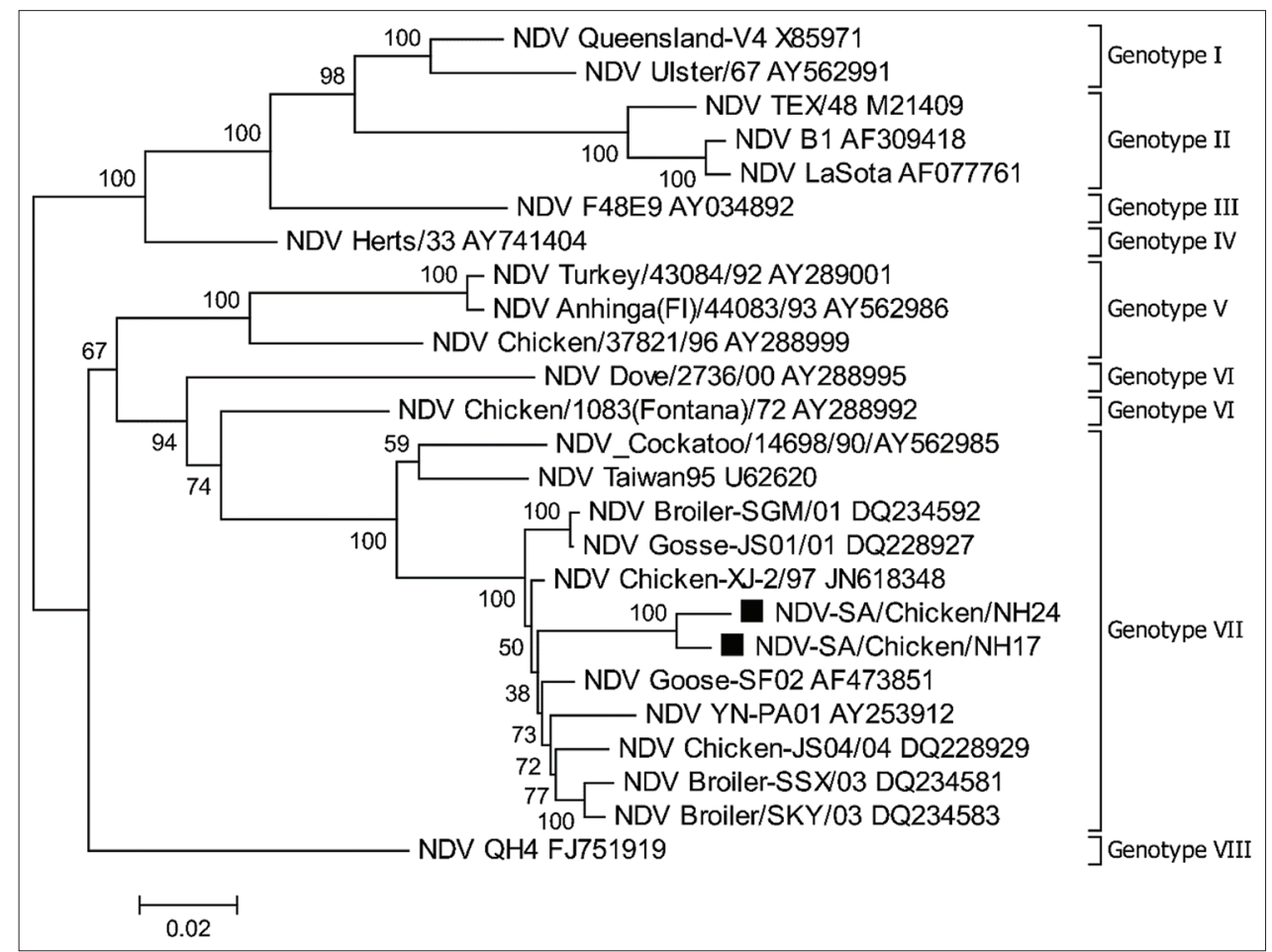

Figure-2: Phylogenetic analysis of complete hemagglutinin-neuraminidase gene sequences. The present Saudi isolates are marked with black squares. Reference sequences end with their GenBank accession numbers.

genotype VII-NDV strain (NDV-SA/Chicken/NH17) was isolated from the same farm 20 days earlier, and a vaccine containing the $\mathrm{B} 1$ strain was applied 11 days before sampling. Alternatively, natural recombination could have occurred at a certain point in time between genotype VII-like and genotype II-like viruses. Similar situations were previously reported in China and Iran [20,35,38-40]. A complete genome sequence of a similar NDV isolate revealed that recombination had occurred at the $\mathrm{N}$ terminus of the $\mathrm{F}$ gene [39].
The present genotype VII isolate shares considerable nucleotide identity with similar strains from the surrounding region, for example, with SMV-8/13 and SMV-4/2012 (GB\# KU201415; KU201419) from Iran and SDSG01/2011 (GB \# JN400896) from China. The trade of poultry and poultry products would be a possible dissemination route for NDV. Alternatively, wild migratory birds might play a possible role in its dissemination; this scenario was proposed for NDV dissemination in nearby Southern Iran [41]. Wild birds 
Table-5: HN gene nucleotide sequence identities of two Saudi isolates with reference sequences from NDV genotypes.

\begin{tabular}{lcc}
\hline Sequence & NDV-SA/Chicken/NH24 & NDV-SA/Chicken/NH17 \\
\hline NDV-SA/Chicken/NH24 & & 0.982 \\
NDV-SA/Chicken/NH17 & 0.982 & 0.96 \\
NDV-Chicken-XJ-2/97/JN618348.1 (VII) & 0.964 & 0.952 \\
NDV-Gosse-JS01/01/DQ228927.1 (VII) & 0.956 & 0.952 \\
NDV-Broiler-SGM/01/DQ234592.1 (VII) & 0.956 & 0.949 \\
NDV-Chicken-JS04/04/DQ228929.1 (VII) & 0.953 & 0.949 \\
NDV-Broiler/SKY/03/DQ234583.1 (VII) & 0.953 & 0.947 \\
NDV-Broiler-SSX/03/DQ234581.1 (VII) & 0.951 & 0.955 \\
NDV-Goose-SF02/AF473851.2 (VII) & 0.958 & 0.943 \\
NDV-YN-PA01/AY253912.1 (VII) & 0.946 & 0.92 \\
NDV-Taiwan95/U62620.1 (VII) & 0.924 & 0.915 \\
NDV-cockatoo/14698/90/AY562985.1 (VII) & 0.918 & 0.881 \\
NDV-Chicken/1083(Fontana)/72/AY288992.1 (VI) & 0.883 & 0.862 \\
NDV-chicken/37821/96/AY288999.1(V) & 0.863 & 0.852 \\
NDV-Herts/33/AY741404.1 (IV) & 0.851 & 0.83 \\
NDV-F48E9/AY034892.1 (III) & 0.828 & 0.815 \\
NDV-LaSota/AF077761.1 (II) & 0.813 & 0.833 \\
NDV-Ulster/67/AY562991.1 (I) & 0.833 & 0.856 \\
NDV-QH4/FJ751919.1 (VIII) & 0.855 & \\
\hline
\end{tabular}

$\mathrm{NDV}=$ Newcastle disease virus, $\mathrm{HN}=$ Hemagglutinin-neuraminidase

have been considered a potential reservoir of NDV. Low virulent NDV was frequently isolated from wild waterfowl. However, there is little evidence to suggest a possible role of wild birds in the dissemination of virulent NDV [42-45].

Vaccination is the primary measure to control ND [32]. The presented data showed that circulating NDVs belong to genotype II and virulent genotype VII. Strains belonging to genotypes VII and VI have been circulating in Saudi Arabia since 2000 and the 1990s, respectively, or even earlier [12]. Whether such a situation necessitates revision of the used vaccines is a controversial question. It has been well documented that NDV is a single serotype and that any strain can confer cross-protection against other strains. Recently, there has been a debate on whether some vaccine strains provide better protection than others depending on the titers of shed virus after challenge $[1,46]$. However, other investigators attribute the variations in virus shedding and even the occurrence of NDV outbreaks to inadequate administration of NDV vaccines [1].

\section{Conclusion}

In vivo biotyping was used to confirm the results of molecular investigations. There were at least two NDV genotypes circulating in the Eastern Region of Saudi Arabia, genotype II and genotype VII. Mixed infection and possible natural recombination between the two genotypes must be considered. Surveillance of poultry respiratory diseases should be continued to optimize the control strategy. The role of wild migratory birds and semi-domesticated birds in the dissemination of NDV and other poultry respiratory pathogens need to be investigated.

\section{Authors' Contributions}

AIAA conceived and designed the study. The author collected the samples and analyzed the data. The author prepared and approved the final manuscript.

\section{Acknowledgments}

The author would like to thank the Deanship of Scientific Research, King Faisal University, Saudi Arabia, for the moral and financial support of this work (Grant number: 140114). The author also would like to thank Dr. Anwar Abdulwali Ghaleb Al-Kubati for his technical support.

\section{Competing Interests}

The author declares that they have no competing interests.

\section{Publisher's Note}

Veterinary World remains neutral with regard to jurisdictional claims in published institutional affiliation.

\section{References}

1. Kapczynski, D.R., Afonso, C.L. and Miller, P.J. (2013) Immune responses of poultry to Newcastle disease virus. Dev. Comp. Immunol., 41(3): 447-453.

2. Alexander, D.J. (1990) Avian paramyxoviridae recent developments. Vet. Microbiol., 23(1-4): 103-114.

3. Alexander, D.J., Bell, J.G. and Alders, R.G. (2004) A Technology Review: Newcastle Disease, with Special Emphasis on its Effect on Village Chickens. Food and Agriculture Organization of the United Nations, Rome, Italy.

4. Li, X., Qiu, Y., Yu, A., Chai, T., Zhang, X., Liu, J., Wang, D., Wang, H., Wang, Z. and Song, C. (2009) Degenerate primers based RT-PCR for rapid detection and differentiation of airborne chicken Newcastle disease virus in chicken houses. J. Virol. Methods, 158(1-2): 1-5.

5. Zanetti, F., Berinstein, A., Pereda, A., Taboga, O. and Carrillo, E. (2005) Molecular characterization and phylogenetic analysis of Newcastle disease virus isolates from healthy wild birds. Avian Dis., 49(4): 546-550.

6. Hossain, M.B., Islam, M.Z., Bari, M.S., Torab, M.A. and Mondal, M.A.H. (2013) Seroprevalence of Newcastle disease virus in backyard chickens at Gazipur district of Bangladesh. Int. J. Nat. Sci., 3(1-4): 22-25.

7. Office International des Epizooties. (2012) Newcastle Disease (Infection with Newcastle Disease Virus). In: Manual of Diagnostic Tests and Vaccines for Terrestrial 
Animals 2019. Ch. 3.3.14. Paris, France: World Organisation for Animal Health. p555-574. Available from: http://www. oie.int/en/standard-setting/terrestrial-manual/access-online. Last accessed on 18-10-2019.

8. Cattoli, G., Susta, L., Terregino, C. and Brown, C. (2011) Newcastle disease: A review of field recognition and current methods of laboratory detection. J. Vet. Diagn. Invest., 23(4): 637-656.

9. Miller, P.J., Decanini, E.L. and Afonso, C.L. (2010) Newcastle disease: Evolution of genotypes and the related diagnostic challenges. Infect. Genet. Evol., 10(1): 26-35.

10. Tirumurugaan, K.G., Kapgate, S., Vinupriya, M.K., Vijayarani, K., Kumanan, K. and Elankumaran, S. (2011) Genotypic and pathotypic characterization of Newcastle disease viruses from India. PLoS One, 6(12): e28414.

11. Bello, M.B., Yusoff, K.M., Ideris, A., Hair-Bejo, M., Peeters, B.P., Jibril, A.H., Tambuwal, F.M. and Omar, A.R. (2018) Genotype diversity of Newcastle disease virus in Nigeria: Disease control challenges and future outlook. $A d v$. Virol., 2018(1): 6097291.

12. Aldous, E.W., Mynn, J.K., Banks, J. and Alexander, D.J. (2003) A molecular epidemiological study of avian paramyxovirus Type 1 (Newcastle disease virus) isolates by phylogenetic analysis of a partial nucleotide sequence of the fusion protein gene. Avian Pathol., 32(3): 239-256.

13. Diel, D., Silva, L., Liu, H., Wang, Z., Miller, P. and Afonso, C. (2012) Genetic diversity of avian paramyxovirus Type 1: Proposal for a unified nomenclature and classification system of Newcastle disease virus genotypes. Infect. Genet. Evol., 12(8): 1770-1779.

14. Mase, M., Imai, K., Sanada, Y., Sanada, N., Yuasa, N., Imada, T., Tsukamoto, K. and Yamaguchi, S. (2002) Phylogenetic analysis of Newcastle disease virus genotypes isolated in Japan. J. Clin. Microbiol., 40(10): 3826-3830.

15. El-Zein, A. (1986) Characterization of a velogenic Newcastle disease virus isolated from broilers in Saudi Arabia. Avian Dis., 30(4): 825-828.

16. Al-Ali, A.M., El-Sabagh, I.M., Mohamed, M.H., Alluwaimi, A.M. and Arif, I.A. (2018) Molecular characterization of common respiratory viral infections in broilers in Al-Hassa, Eastern Province, Saudi Arabia. Thai. J. Vet. Med., 48(2): 235-245.

17. Ministry of Environment Water and Agriculture. (2018) Statistical Data 2015. Ministry of Environment, Water and Agriculture, Riyadh, Saudi Arabia. Available from: https://www.mewa.gov.sa/ar/InformationCenter/Researchs/ StaticticsData/Pages/default.aspx\#collapseOne8. Last accessed on 12-11-2018.

18. Ministry of Environment Water and Agriculture. (2017) The Statistical Book 2017. 1438/1439 $9^{\text {th }}$ ed. Ministry of Environment, Water and Agriculture, Riyadh, Saudi Arabia. Available from: https://www.mewa.gov.sa/ar/ InformationCenter/Researchs/Reports/Pages/default.aspx. Last accessed on 19-10-2019.

19. Nanthakumar, T., Kataria, R.S., Tiwari, A.K., Butchaiah, G. and Kataria, J.M. (2000) Pathotyping of Newcastle disease viruses by RT-PCR and restriction enzyme analysis. Vet. Res. Commun., 24(4): 275-286.

20. Tan, L.T., Xu, H.Y., Wang, Y.L., Qin, Z.M., Sun, L., Liu, W.J. and Cui, Z.Z. (2008) Molecular characterization of three new virulent Newcastle disease virus variants isolated in China. J. Clin. Microbiol., 46(2): 750-753.

21. Kumar, S., Stecher, G., Li, M., Knyaz, C. and Tamura, K. (2018) MEGA X: Molecular evolutionary genetics analysis across computing platforms. Mol. Biol. Evol., 35(6): 1547-1549.

22. Snoeck, C.J., Owoade, A.A., Couacy-Hymann, E., Alkali, B.R., Okwen, M.P., Adeyanju, A.T., Komoyo, G.F., Nakouné, E., Le Faou, A. and Muller, C.P. (2013) High genetic diversity of Newcastle disease virus in poultry in West and Central Africa: Cocirculation of genotype XIV and newly defined genotypes XVII and XVIII. J. Clin.
Microbiol., 51(7): 2250-2260.

23. Dimitrov, K.M., Abolnik, C., Afonso, C.L., Albina, E., Bahl, J., Berg, M., Briand, F.X., Brown, I.H., Choi, K.S. and Chvala, I. (2019) Updated unified phylogenetic classification system and revised nomenclature for Newcastle disease virus. Infect. Genet. Evol., 74(2019): 103917.

24. Dimitrov, K.M., Ramey, A.M., Qiu, X., Bahl, J. and Afonso, C.L. (2016) Temporal, geographic, and host distribution of avian paramyxovirus 1 (Newcastle disease virus). Infect. Genet. Evol., 39(2016): 22-34.

25. Alexander, D. (1998) Newcastle disease and other avian paramyxoviruses. In: Swayne, D.E., Glisson, J.R., Jackwood, M.W., Pearson, J.E. and Reed, W.R., editors. A Laboratory Manual for the Isolation and Identification of Avian Pathogens. ${ }^{\text {th }}$ ed. American Association of Avian Pathologists University of Pennsylvania, Kennett Square, PA. p156-163.

26. Grimes, S.E. (2002) A Basic Laboratory Manual for the Small-Scale Production and Testing of I-2 Newcastle Disease Vaccine. FAO-APHCA, Bangkok, Thailand.

27. Hasan, A.R., Ali, M., Siddique, M., Rahman, M. and Islam, M. (2010) Clinical and laboratory diagnoses of Newcastle and infectious bursal diseases of chickens. Bangladesh J. Vet. Med., 8(2): 131-140.

28. Roussan, D., Haddad, R. and Khawaldeh, G. (2008) Molecular survey of avian respiratory pathogens in commercial broiler chicken flocks with respiratory diseases in Jordan. Poult. Sci., 87(3): 444-448.

29. Ayim-Akonor, M., Baryeh, K. and Asante, I. (2013) Molecular based survey of pathogens associated with respiratory disease outbreaks in broiler chickens in Accra. J. Nat. Sci. Res., 3(10): 25-31.

30. Zaher, K.S. and Girh, Z.M.A. (2014) Concurrent infectious bronchitis and Newcastle disease infection in Egypt. Br. J. Poult. Sci., 3(1): 1-5.

31. Thomazelli, L., de Araujo, J., Ferreira, C.D.S., Hurtado, R., Oliveira, D., Ometto, T., Golono, M., Sanfilippo, L., Demetrio, C. and Figueiredo, M. (2012) Molecular surveillance of the Newcastle disease virus in domestic and wild birds on the North-Eastern Coast and Amazon biome of Brazil. Rev. Bras. Cienc. Avic., 14(1): 1-7.

32. Rauw, F., Gardin, Y., Palya, V., van Borm, S., Gonze, M., Lemaire, S., van den Berg, T. and Lambrecht, B. (2009) Humoral, cell-mediated and mucosal immunity induced by oculo-nasal vaccination of one-day-old SPF and conventional layer chicks with two different live Newcastle disease vaccines. Vaccine, 27(27): 3631-3642.

33. Umali, D.V., Ito, H., Suzuki, T., Shirota, K., Katoh, H. and Ito, T. (2013) Molecular epidemiology of Newcastle disease virus isolates from vaccinated commercial poultry farms in non-epidemic areas of Japan. Virol. J., 10(1): 330.

34. Liu, X.F., Wan, H.Q., Ni, X.X., Wu, Y.T. and Liu, W.B. (2003) Pathotypical and genotypical characterization of strains of Newcastle disease virus isolated from outbreaks in chicken and goose flocks in some regions of China during 1985-2001. Arch. Virol., 148(7): 1387-1403.

35. Rui, Z., Juan, P., Jingliang, S., Jixun, Z., Xiaoting, W., Shouping, Z., Xiaojiao, L. and Guozhong, Z. (2010) Phylogenetic characterization of Newcastle disease virus isolated in the mainland of China during 2001-2009. Vet. Microbiol., 141(3-4): 246-257.

36. Yu, L., Wang, Z., Jiang, Y., Chang, L. and Kwang, J. (2001) Characterization of newly emerging Newcastle disease virus isolates from the people's republic of China and Taiwan. $J$. Clin. Microbiol., 39(10): 3512-3519.

37. Lomniczi, B., Wehmann, E., Herczeg, J., Ballagi-Pordany,A., Kaleta, E.F., Werner, O., Meulemans, G., Jorgensen, P.H., Mante, A.P., Gielkens, A.L., Capua, I. and Damoser, J. (1998) Newcastle disease outbreaks in recent years in Western Europe were caused by an old (VI) and a novel genotype (VII). Arch. Virol., 143(1): 49-64.

38. Yin, Y., Cortey, M., Zhang, Y., Cui, S., Dolz, R., Wang, J. and 
Gong, Z. (2011) Molecular characterization of Newcastle disease viruses in ostriches (Struthio camelus L.): Further evidence of recombination within avian paramyxovirus Type 1. Vet. Microbiol., 149(3-4): 324-329.

39. Qin, Z., Sun, L., Ma, B., Cui, Z., Zhu, Y., Kitamura, Y. and Liu, W. (2008) F gene recombination between genotype II and VII Newcastle disease virus. Virus Res., 131(2): 299-303.

40. Ghalyanchi-Langeroudi, A., Hosseini, H., Madadgar, O., Karimi, V., Shahraeini, A. and Ghafari, M. (2011) Sequence analysis of fusion gene of Newcastle disease viruses isolated from ostrich (Struthio camelus) in Iran, 2012. Iran J. Virol., 5(3): 12-17.

41. Mehrabanpour, M., Fazel, P., Rahimian, A., Hosseini, M., Moein, H. and Shayanfar, M. (2011) Newcastle disease and avian Influenza A virus in migratory birds in wetland of Boushehr-Iran. Int. J. Anim. Vet. Adv., 3(4): 229-234.

42. Ahmed, A., Sabban, M., Ibrahim, A., Amin, A., Khafagi, A. and Sheble, A. (1980) Some properties of Newcastle disease virus isolates recovered from migratory birds to Egypt. Zentralbl. Veterinarmed. B, 27(4): 313-319.

43. Alexander, D. and Senne, D. (2008) Newcastle disease, other avian paramyxoviruses, and pneumovirus infections. In: Saif, Y.M., Fadly, A.M., Glisson, J.R., McDougald, L.R., Nolan, L.K. and Swayne, D.E., editors. Diseases of Poultry. $12^{\text {th }}$ ed. Blackwell Publishing, Ames, IA, USA. p75-99.

44. Alexander, D.J. (2011) Newcastle disease in the European Union 2000 to 2009. Avian Pathol., 40(6): 547-558.

45. Takakuwa, H., Ito, T., Takada, A., Okazaki, K. and Kida, H. (1998) Potentially virulent Newcastle disease viruses are maintained in migratory waterfowl populations. Jpn. J. Vet. Res., 45(4): 207-215.

46. Roohani, K., Tan, S.W., Yeap, S.K., Ideris, A., Bejo, M.H. and Omar, A.R. (2015) Characterisation of genotype VII Newcastle disease virus (NDV) isolated from NDV vaccinated chickens and the efficacy of LaSota and recombinant genotype VII vaccines against challenge with velogenic NDV. J. Vet. Sci., 16(4): 447-457.

$* * * * * * * *$ 